\title{
REKAYASA MESIN PENCETAK KAMPAS REM SERAT PULP NON ASBESTOS
}

\author{
Wawan Kartiwa Haroen \\ Reza Bastari Watimena \\ Balai Besar Pulp dan Kertas (BBPK) Bandung \\ Email: wawankh@yahoo.com
}

\begin{abstract}
ABSTRAK
Mesin pembuat kampas rem non asbestos berbahan serat pulp merupakan kampas hasil inovasi komponen otomotif yang memiliki keunggulan diantaranya, sifat gesek tinggi, tahan panas dan bebas asbes. Telah dilakukan penelitian perekayasaan mesin pembuat kampas rem berbahan serat pulp skala kecil, dapat digunakan langsung sebagai alat produksi skala kecil atau untuk mensosialisasikan proses penelitian berbagai variasi bahan baku kampas rem. Mesin ini terdiri dari dua bagian yaitu mesin pengurai serat, pengaduk dan pembuat kampas rem serat pulp jenis rem cakram (disk brake). Mesin pengurai berfungsi untuk memisahkan serat pulp menjadi serat yang terurai secara individu, mesin pengaduk berfungsi untuk mengaduk atau mencampur anatar serat pulp dengan bahan aditif pengikat. Alat pengurai dan pengaduk dioperasikan dengan motor listrik 1.000 watt, dilengkapi pengatur kecepatan (reducer speed) dan screw feeder. Alat pembuat kampas rem dioperasikan oleh motor listrik 2.000 watt, pompa press 10 ton dan pemanas 40-200 oC. Mesin ini dioperasikan semi otomatis dengan konsumsi listrik 3.000 watt, dilengkapi pengontrol temperatur, pengatur kecepatan putaran (rpm) dan pengatur daya tekan. Mesin pencetak kampas rem hasil rekayasa dapat memproduksi 10-15 specimen kampas rem cakram /jam.
\end{abstract}

Kata kunci: rekayasa, pengurai, pencetak kampas rem, rem cakram, serat pulp,

\section{ABSTRACT}

Machinery maker non-asbestos brake linings made from pulp fiber is the result of innovation canvass automotive components which have advantages including, high frictional properties, heatresistant and asbestos-free. Engineering studies have been conducted maker brake linings made from small-scale pulp fibers, can be used directly as a means of small-scale production or to disseminate the research process a wide variety of brake lining material. This machine consists of two parts: the fiberizer, stirrer and brake maker of fiber pulp type disc brakes (disc brake). Fiberizer engine serves to separate the pulp fibers into individual fibers, mixer serves to stir or mix the pulp fibers and additive binder. Fiberizer tool and stirrer operated with a 1000 watt electric motor, equipped with speed control (speed reducer) and screw feeder. Tool maker brake is operated by a 2,000 watt electric motor, pump and heater press 10 tons of $40-200^{\circ} \mathrm{C}$. This machine is operated semi-automatic with a power consumption of 3,000 watts, equipped with temperature control, regulating the speed (rpm) and press the power regulator. Printer engine brake can be modified to produce a 10-15 specimens brake discs / hour.

Keywords: engineering, defiberizer, brake equipment, discs brake, fiber pulp.

\section{PENDAHULUAN}

Kampas rem merupakan salah satu komponen kendaraan bermotor yang berfungsi untuk memperlambat atau menghentikan laju kendaraan khususnya kendaraan darat. Terutama pada saat kendaraan berkecepatan tinggi, fungsi kanvas rem memiliki beban mencapai $90 \%$ dari komponen lainnya, bahkan keselamatan manusia tergantung pada keampuhan dari komponen tersebut. Suatu tanda pada komponen kendaraan ada yang bertuliskan OEM (Original Equipment Manufactured) yaitu kampas rem yang terpasang pada saat kita membeli kendaraan baru dari dealer. Tanda OES (Original Equipment Spare part) yaitu kampas rem yang digunakan sebagai pengganti kampas rem OEM, kampas rem ini dibuat oleh pabrikan OEM yang memiliki persamaan pada formula, proses pembuatan, kualitas dan bahan yang sama dengan kampas rem OEM. Namun ada suku cadang yang disebut After market yaitu kampas rem yang beredar di pasaran dengan kualitas yang beragam, misalnya lebih rendah dari OEM atau lebih tinggi dari OEM. Satu lagi yang sering kita jumpai yaitu sebutan Genuine, tanda tersebut pada dasarnya adalah kampas rem tergolong kedalam kategori after market, istilah genuine hanya untuk 
membedakan antara asli dan palsu [7]. Komponen kampas rem perlu mendapat perhatian terutama kualitas dan isi bahan yang mengacu pada standar nasional atau internasional. Kampas rem umumnya terdiri dari bahan asbestos yang memiliki satu jenis fiber yaitu asbes, saat ini debu asbes merupakan komponen berefek carsinogenik. Maka serat asbes mulai ditinggalkan dan beralih ke kampas rem serat non asbestos. Untuk melakukan penelitian dan uji coba berbagai serat sebagai pengisi kampas rem telah dirancang suatu alat pencetak kampas rem non asbestos dan dapat berfunsi juga sebagai alat produksi skala kecil..

Berdasarkan penelusuran dari berbagai pustaka [1] tentang pembuatan kampas rem umumnya dimulai dari persiapan, penguraian, pemilihan bahan, penambahan aditif, pengadukan dan pencetakan [3][6]. Gagasan untuk membuat alat pengurai, pengaduk dan pencetak kampas rem dengan bahan pengisi serat pulp perlu disosialisasikan kepada masyarakat pengguna dan industri. Dari hasil penelitian kampas rem pulp terdapat perbedaan mendasar pada karakteristik bahan pengisi serat asbes dan serat pulp [7][8]. Untuk menanggulangi masalah tersebut perlu dilakukan modifikasi terhadap serat pulp menggunakan alat yang dirancang khusus. Pulp yang telah dimodifikasi dapat dijadikan sebagai bahan pengisi kampas rem penggati asbes yang memiliki sifat serat mudah menyatu dengan aditif lainnya. Gagasan untuk melakukan rekayasa alat untuk memodifikasi serat pulp terdiri dari alat pengurai, pencampur, dan pengaduk yang menghasilkan campuran kampas rem siap dicetak [6][2][4].

Rekayasa pembuatan alat ini bertujuan untuk mensosialisasikan kepada masyarakat industri dan pemakai otomotif tentang kampas rem serat pulp dan prosesnya. Hasil kajian tersebut diperoleh pradisain alat pengurai, pengaduk dan pencampur serat pulp. Satu alat lainnya yaitu pencetak kampas rem tidak banyak perubahan kecuali kapasitas produksinya yang disesuaikan. Rekayasa alat pencetak kampas rem pulp terdiri dari 2 bagian yaitu : mesin pengurai, pengaduk pulp + aditif dan satu alat lagi yaitu pencetak kampas rem.

Hasil rekayasa ini akan berwujud sebagai prototipe mesin yang berfungsi sebagai mesin produksi kampas rem kendaraan. Unit ini dioperasikan dengan listrik 220 Volt, untuk menjalankan dinamo, screw, kompresor dan pemanas. Pelaksanaan perekayasaan bekerja sama dengan bengkel teknik, dimulai dari perencanaan model yang dikomunkasikan dengan pakar otomotif. Hasilnya diolah dan diproses untuk memilih material dan disain alat sesuai dengan spesifikasinya. Proses pembuatan disain sampai menjadi alat diperlukan waktu 100 hari kerja. Hasilnya berupa satu unit alat pencetak kampas rem mini berbahan baku serat pulp. Produk yang dihasilkan dari mesin rekayasa, berupa rem jenis cakram (disk brake) untuk roda dua dan roda empat.

\section{BAHAN DAN METODA}

\subsection{Bahan}

Bahan terdiri dari besi plat, besi siku, mur/baut, kabel, kumparan pemanas, konektor, termostat, motor listrik 220 volt, V-belt, tabung \& pipa pneumatik, compresor, handle pompa tekanan, reducer rpm, timer dan tombol listrik

\subsection{Peralatan}

Peralatan yang dipergunakan pada pembauatan alat pencetak kampas rem diantaranya mesin pemotong, mesin las listrik, mesin press, gerinda, mesin bor, kompresor, peraalatan ukur, pengecor logam, tachometer digital, dan kunci shock pembuka .

\subsection{Metoda}

Metoda rekayasa dilakukan melalui 2 tahap yaitu disain gambar dan pembuatan mesin. Pelaksanaan dimulai dari pra- draft disain, pembuatan gambar teknik pengurai dan pencetak (blue print) (Gambar 1,2). Dilanjutkan dengan pemilihan dan pencarian bahan-bahan yang digunakan, diskusi dengan bengkel teknik, pelaksanaan pembuatan mesin. Setiap ada perubahan disain selalu berkolaborasi dengan pakar teknik mesin secara intensif dengan tim peneliti supaya dapat menghasilkan spesifikasi yang sesuai. Tahapan (alur) pelaksanaan perekayasaan dan penelitian pembuatan pencetak kampas rem untuk serat pulp (non asbestos) tertera pada Gambar 1 . 


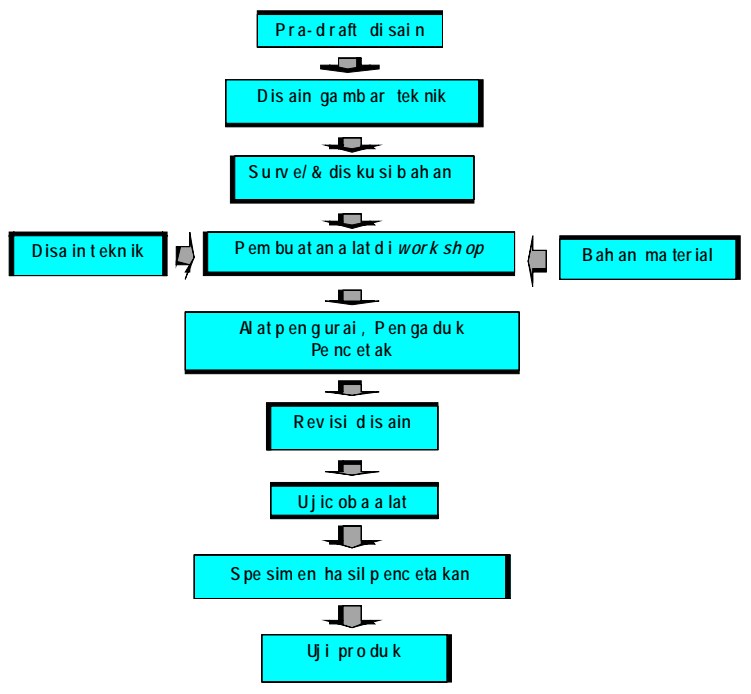

\section{Gambar 1. Diagram Alir Rekayasa Pencetak Kampas Rem Serat Pulp}

Uji coba dilakukan terhadap kinerja mesin kampas rem saat proses penguraian serat pulp menjadi serat secara terpisah, pengadukan pulp dengan aditif sampai diperoleh campuran yang homogen siap menjadi adonan utama kampas rem dan kinerja pada saat pencetakan kampas rem. Jenis cakram. Rangkaian proses secara keseluruhan dilaksanakan sesuai spesifikasi alat seperti suhu dan tekanan minimal -maksimal. Suhu antara $100-150^{\circ} \mathrm{C}$ dan tekanan 3-4 Psi sampai diperoleh campuran homogen. Pengamatan waktu pencetakan. Kualitas produk kampas rem cakram siap pakai.
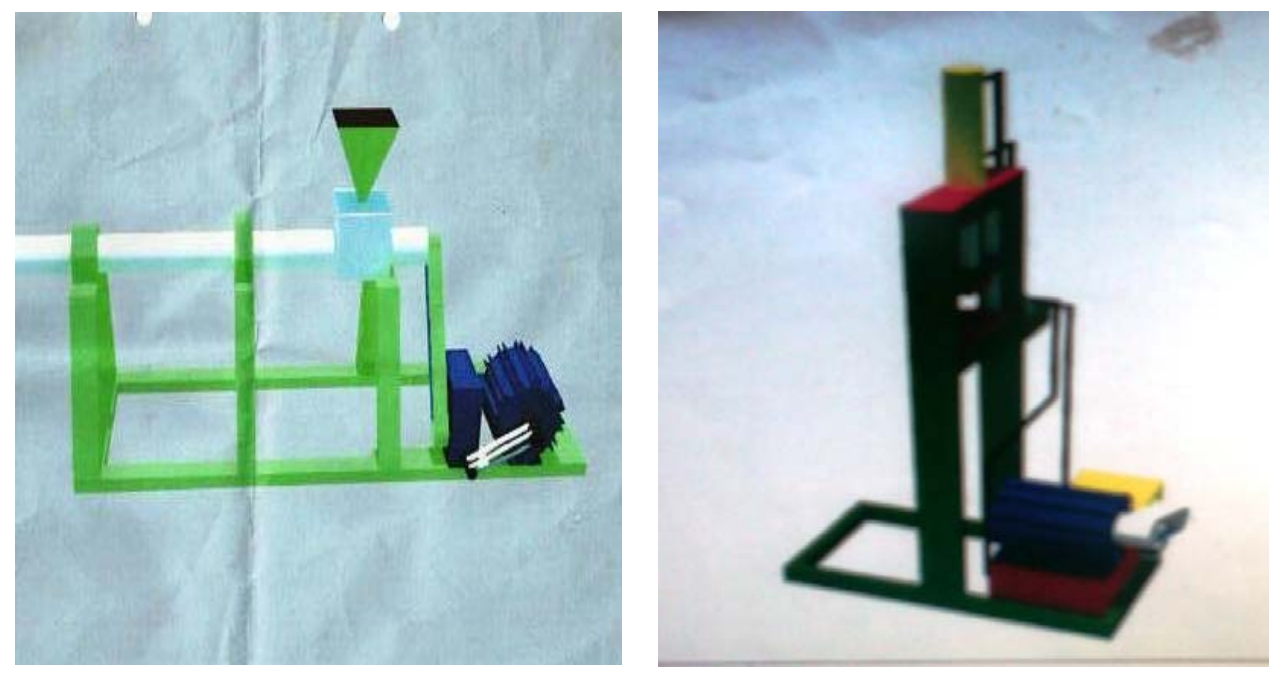

Gambar 2. Pra-disain Alat Pengaduk Dan Pencetak Kampas Rem Serat Pulp

\section{HASIL REKAYASA DAN PEMBAHASAN}

Mesin pencetak kampas rem pulp di rancang khusus untuk industri kecil atau untuk alat simulasi penelitian di laboratorium. Mesin terdiri dari 2 unit yang terpisah, namun alat ini saling berkaitan menjadi satu unit proses (Gambar 3). Mesin pertama berupa alat pengurai dan pengaduk, mesin kedua berupa mesin pencetak dan pengepres. Setiap unit memiliki spesifikasi yang berbeda sesuai dengan fungsinya. Secara rinci spesifikasi dari masing-masing alat yang dirancang melalui kajian penelitian dan perekayasaan, diuraikan berikut ini. 


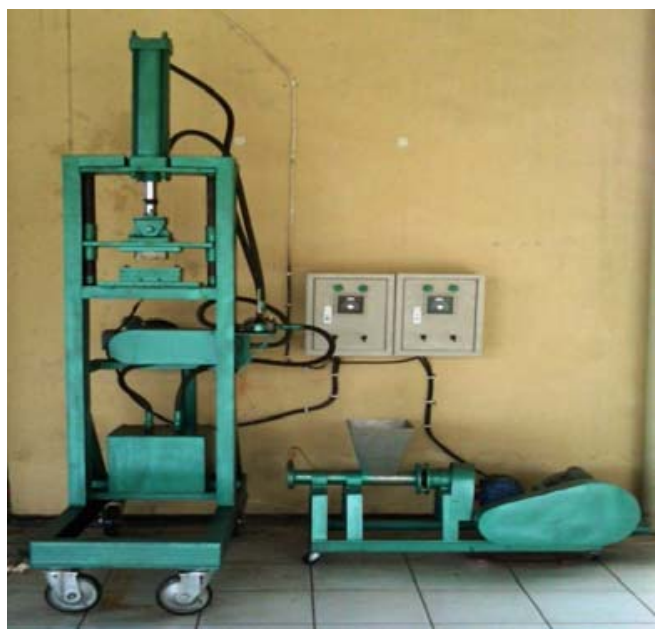

\section{Gambar 3. Pencetak Kampas Rem Serat Pulp Hasil Rekayasa}

\subsection{Mesin Pengurai \& Pengaduk Terdiri Dari}

1) Motor listrik 1,0 HP, 3 Amper, $50 \mathrm{~Hz}, 1420 \mathrm{rpm}$ class $\mathrm{E}$.

2) Worm Gear Motor Reducer (WGM), size 70, ratio 30 buatan Taiwan. Berfungsi untuk menurunkan putaran bagian screw sebagai alat pengurai dan pengaduk, kecepatan semakin lambat akan memberikan pengadukan yang baik dan homogen dibandingkan dengan kecepatan lebih cepat.

3) 15 buah ulir diameter $80 \mathrm{~mm}$, jarak antara ulir $30 \mathrm{~mm}$, bahan terbuat dari stell. Ulir berputar kearah kanan menyerupai ulir sekrup dan berfungsi untuk menguraikan serat pulp menjadi individu serat yang terpisah dan mengaduk campuran antara aditif dengan serat pulp menjadi homogen pada waktu tertentu.

4) Lubang pengumpan bahan baku bagian atas $200 \mathrm{~mm} \times 200 \mathrm{~mm}$, bagian bawah $70 \mathrm{~mm} \times 100 \mathrm{~mm}$, tinggi $230 \mathrm{~mm}$ terbuat dari bahan lembaran tebal $2 \mathrm{~mm}$. Lubang penguman digunakan untuk memasukan bahan-bahan yang akan diproses dan untuk mengeluarkan bahan hasil proses (adonan) untuk dibuat kampas rem pulp

5) 2 buah pully berdiamater $200 \mathrm{~mm}$ dan $120 \mathrm{~mm}$, dihubungkan dengan van belt $400 \mathrm{~mm}$. Berfungsi untuk menghubungkan antara motor penggerak dengan alat reducer rpm dengan bantuan $V$-belt.

6) Tabung pengaduk sepanjang $750 \mathrm{~mm}$ terbuat dari stell dilengkapi dengan kumparan pemanas.Tabung difungsikan sebagai ruang pengadukan bertekanan, dilengkapi dengan pemanas supaya proses pengadukan bahan baku tercampur sempurna dan homogen secara baik.

7) Lubang pengeluaran bahan baku hasil proses dengan diameter $120 \mathrm{~mm}$, letak lubang berada dibagian ujung tabung pengaduk dan memiliki lubang-lubang kecil, material yang dikeluarkan merupakan bahan baku campuran untuk kampas rem siap cetak.

8) Operasi mesin dihubungkan dan dikendalikan dengan panel kontrol (Gambar 4 dan Tabel 1).

9) Rangka mesin terbuat dari besi siku $50 \mathrm{~mm} \times 90 \mathrm{~mm}$ dilengkapi 4 buah roda, untuk memudahkan pemindahan alat.
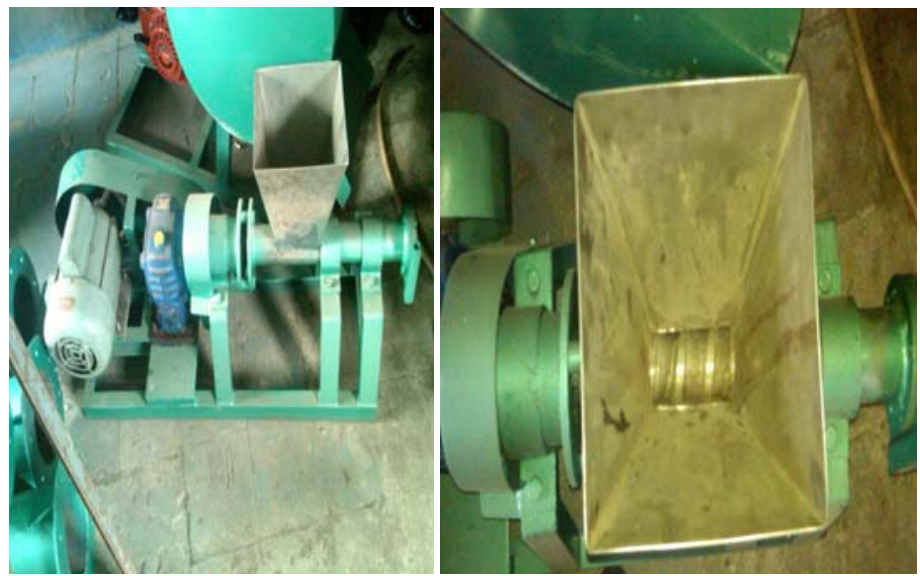

Gambar 4. Pengaduk dan Pengurai Serat Pulp 
Tabel 1. Spesifikasi alat pengaduk kampas rem pulp

\begin{tabular}{ll}
\hline \multicolumn{1}{c}{ Komponen } & \multicolumn{1}{c}{ Spesifikasi } \\
\hline Motor listrik & Motor listrik 1,0 HP, 3 Amper, $50 \mathrm{~Hz}, 1.420 \mathrm{rpm}$ \\
& klass E buatan Taiwan. \\
Screw & 15 ulir berdiameter $80 \mathrm{~mm}$, jarak $30 \mathrm{~mm}$, \\
& terbuat dari \\
Reducer RPM & Worm Gear Motor $(\mathrm{WGM})$, size 70, ratio 30 \\
& buatan Taiwan \\
Heater & 1.000 Watt, 220 Volt \\
Panel kontrol & Pengatur suhu 40-200 ${ }^{\circ} \mathrm{C}$ \\
& Break-cut \\
& Tombol on/off, \\
Rangka & Besi UNP dilapisi cat anti karat dan dilengkapi 4 \\
& buah roda \\
Dimensi alat & $900 \mathrm{~mm} \times 50 \mathrm{~mm}$ \\
Berat mesin & $\pm 70 \mathrm{~kg}$ \\
\hline
\end{tabular}

Mesin ini berfungsi untuk menguraikan serat pulp menjadi serat yang terpisah, menjadi serat individu dan bagian ini dapat berfungsi juga sebagai pengaduk atau pencampur pulp dengan aditif kampas rem. Pengadukan dapat dintergrasikan dengan pemanas (heater) untuk mempercepat dan menghomogenkan campuran. Pengadukan dan pemanasan dilakukan pada ulir penggerak (screw) yang berputar kontinyu sampai diperoleh campuran yang diinginkan (Gambar 4). Hasil dari proses pengadukan dari mesin ini berupa formula (campuran adonan) kampas rem pulp siap cetak pada mesin pencetak (Gambar 5).

\subsection{Mesin Pencetak Terdiri Dari :}

1) Motor listrik 1,0 HP, 3 Ampere, $50 \mathrm{~Hz}, 1.420 \mathrm{rpm}$ class E buatan Taiwan. Alat ini berfungsi untuk menjalankan pompa tekan dan mengatur kestabilan tekanan.

2) Tabung pompa tekan terbuat dari dengan tinggi $75 \mathrm{~mm}$, diameter $12 \mathrm{~mm}$. Berfungsi sebagai alat penekan/pompa dan mendistribusikan tekanan melalui pipa penghubung distribusi.

3) Tunkai Vicking penggerak tekanan wolvercine model 201205, berfungsi sebagai tuas pengungkit untuk naik turunnya alat press pada saat pencetakan.kampas rem.

4) Pipa/slang penghubung tekanan berukuran 1/2 inchi, EN 8532 SNDM 12, WP 1276 Bar, 4.000 Psi. Berfungsi untuk menyalurkan/mendistribusikan tekanan dari pompa ke alat penecetak kampas rem pada moulding/dyes supaya proses pencetakan berlangsung secara merata dan dapat mengeras dengan bantuan panas saat pencetakan.

5) Dudukan pencetak (moulding) kampas rem cakram, terbuat dari sesuai bentuk atau jenis kampas rem yang akan dicetak.

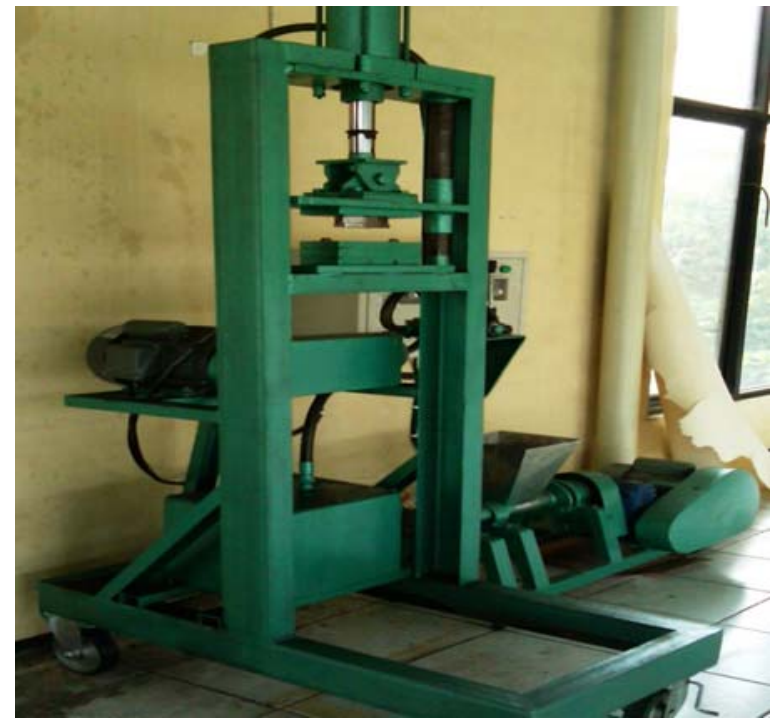

Gambar 5. Mesin Pencetak Kampas Rem Serat Pulp 
Tabel 2. Spesifikasi pencetak kampas rem

\begin{tabular}{cc}
\hline Komponen & Spesifikasi \\
\hline Motor listrik & $2 \mathrm{PK}, 1$ phase \\
Pompa tekan & 10 ton , dilengkapi pipa flexible \\
Heater & 1.000 watt, 220 volt \\
Matres & VCL-140 \\
Kelistrikan \& & Stabilizer panas \\
Panel kontrol & Temperatur 40-200 ${ }^{\circ} \mathrm{C}$ \\
& Tekanan 10 Psi \\
Rangka & UNP 100, cat anti karat \\
& dilengkapi 4 buah roda \\
Ukuran/ dimensi & 500 mm x 500 mm x $1,700 \mathrm{~mm}$ \\
Matres & 4 buah plat \\
Berat alat & $\pm 115 \mathrm{~kg}$ \\
\hline
\end{tabular}

Mesin ini difungsikan sebagai alat cetak untuk memproduksi kampas rem pulp jenis cakram (disk brake) kendaraan roda empat atau roda dua siap pakai.

\subsection{Uji Coba Mesin}

Uji coba tahap awal dilakukan secara langsung untuk pembuatan kampas rem pulp jenis cakram (disk brake) menggunakan mesin pencetak hasil rekayasa. Percobaan dilakukan terhadap kemampuan dan kinerja mesin untuk menghasilkan kampas rem jenis cakram (disk). Hasil uji coba tahap pertama, diperlukan penyesuaian/perubahan dan perbaikan cara kerja alat dengan mengoreksi beberapa komponen supaya kinerjanya dapat bekerja sempurna. Uji coba dilakukan secara berulang-ulang sampai diperoleh hasil yang baik. Adanya perubahan, perbaikan beberapa komponen dan merubah sistim kerja mesin. Hasilnya menujunkkan bahwa pencetak kampas rem (gambar 5) dapat berfungsi dan bekerja sesuai spesifikasi untuk menghasilkan produk kampas rem cakram kendaraan roda dua atau roda empat standar (Tabel 2 dan 3). Spesifikasi dari mesin ini masih dimungkinkan untuk dilakukan perubahan atau modifikasi untuk memperoleh produk dan kualitas optimal, sesuai keinginan pembuatnya. Hasil pemantauan waktu proses yang diperlukan untuk beberapa tahapan seperti penguraian serat pulp pada mesin pengurai (gambar 4) berlangsung selama 10 menit atau sampai serat terurai. Kemudian serat pulp yang terurai ditambahkan aditif (Wawan, 2009. Paten P.00200900599) dan diaduk selama 15 menit sampai campuran homogen. Campuran kemudian dicetak pada mesin pencetak (Gambar 6), proses pencetakan berlangsung selama 15 menit . Hasil kampas rem yang dihasilkan didinginkan dan kemudian dilakukan finising atau penghasulsan menggunakan ampelas kasar dan halus. Produk yang sudah jadi kemudian dilakukan pengujian terhadap daya tekan makimal pada tiap tahap. Pengujian fisik hasil pencetakan kampas rem dari mesin pencetak ini dilakukan terhadap tingkat kekerasan, daya gesek , kekuatan gesek dan koefisien gesek dan suhu pengereman dilaboratorium uji otomotif B4T dan analisa SEM di PPTM hasilnya (tabel 4 dan gambar 7). Pengujian dilakukan pada pengereman pertama suhu pengereman $67^{\circ} \mathrm{C}$, memiliki daya gesek $587 \mathrm{~N}$ dengan kekuatan gesek $256 \mathrm{~N}$ pada tingkat kekerasan 0,49 . Kemudian dilanjutkan pada tahapan pengereman sceara vertahap sampai pengereman ke 20 diperoleh suhu pengereman mencapai $92^{\circ} \mathrm{C}$, memiliki daya gesek $540 \mathrm{~N}$ dengan kekuatan gesek $292 \mathrm{~N}$, pada tingkat kekerasan kampas rem 0,3. Berdasarkan data yang diperoleh menujukkan bahwa kampas rem yang dihasilkan dapat memenuhi kriteria kampas rem standar.

Kapasitas optimal mesin pencetak kampas rem ,dapat memproduksi kampas rem cakram 10-15 specimen /jam, tergantung jenis dan ukurannya. Dari kajian produk kampas rem yang dihasilkan dari alat pecetak hasil rekayasa ini, diperoleh jenis dan kualitas kampas rem cakram yang baik (Tabel 3 dan Gambar 7). Bersadarkan hasil dan data yang diperolek menunjukkan bahwa kinerja mesin pencetak kampas rem serat pulp, dapat berfungsi sebagai alat produksi siap pakai skala kecil dan dapat digunakan sebagai alat uji coba atau peragaan proses pembuatan kampas rem serat pulp (non asbestos) atau bahan baku lainnya untuk kendaraan roda dua atau roda empat. 


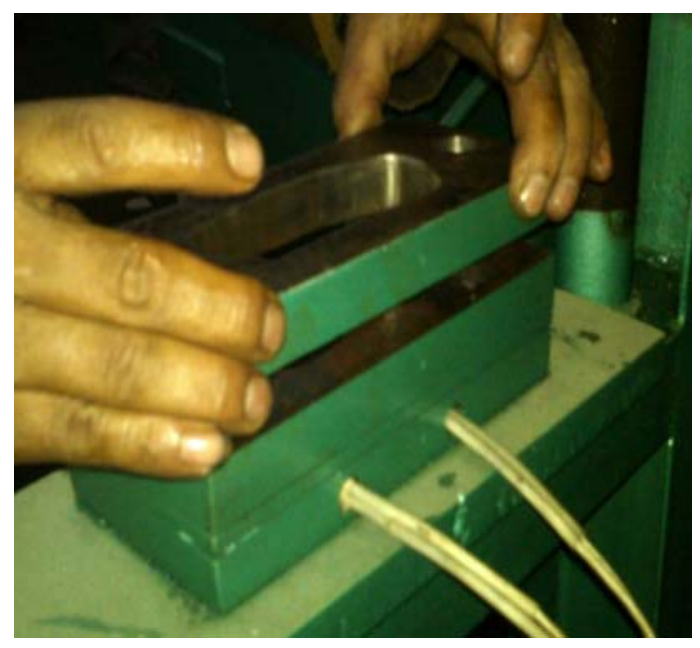

Gambar 6. Cetakan (Moulding) Kampas Rem Serat Pulp Jenis Cakram

Tabel 3. Fungsi kerja alat

\begin{tabular}{llcl}
\hline \multicolumn{1}{c}{ Alat } & \multicolumn{1}{c}{ Bahan } & $\begin{array}{c}\text { Waktu proses } \\
\text { (menit) }\end{array}$ & \multicolumn{1}{c}{ Hasil/Keluaran } \\
\hline Pengurai & Serat pulp & 10 & $\begin{array}{l}\text { Serat pulp terurai } \\
\text { Campuran/adonan } \\
\text { Pengaduk }\end{array}$ \\
& Serat pulp dan aditif & 15 & Kampas rem siap cetak \\
Pencetak & $\begin{array}{l}\text { Campuran /adonan rem cakram } \\
\text { kampas rem, pad besi }\end{array}$ & 15 & \\
& kampas rem & & \\
\hline
\end{tabular}

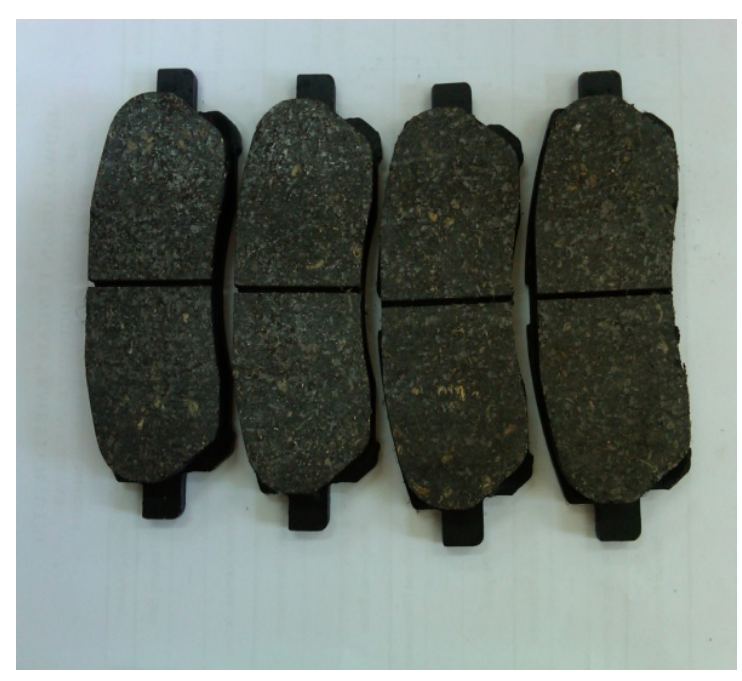

Gambar 7. Kampas Rem Cakram Serat Pulp Dicetak Dengan Mesin Rekayasa

Tabel 4 . Hasil uji produk kampas rem

\begin{tabular}{ccccc}
\hline $\begin{array}{c}\text { Pengujian } \\
\text { tahap }\end{array}$ & $\begin{array}{c}\text { Suhu } \\
\text { Pengereman } \\
(\boldsymbol{C})\end{array}$ & $\begin{array}{c}\text { Daya } \\
\text { gesek } \\
(\boldsymbol{N})\end{array}$ & $\begin{array}{c}\text { Kekuatan } \\
\text { gesek } \\
(\boldsymbol{N})\end{array}$ & $\begin{array}{c}\text { Koefisien } \\
\text { gesek }\end{array}$ \\
\hline 1 & 67 & 587 & 256 & 0.49 \\
5 & 68 & 518 & 291 & 0.47 \\
10 & 92 & 564 & 274 & 0.49 \\
15 & 91 & 549 & 289 & 0.53 \\
20 & 92 & 540 & 293 & 0.53 \\
& kampas rem dengan kekerasan $7,0-8,0$ & \\
\hline
\end{tabular}




\section{KESIMPULAN}

Hasil penelitian dan perekayasaan mesin pembuat kampas rem berbahan baku serat pulp (non asbestos), terdiri dari alat pengurai, pengaduk dan pencetak berkapasitas 10-15 specimen/jam yang dioperasikan dengan listrik 3.000 watt. Komponen dan bahan bahan pencetak tkampas rem dari besi UNP anti karat, besi siku galvanis dan motor listrik 2 fase. Mesin terdiri dari unit pengurai, pengaduk berbentuk screw berulir 15 buah berputar kontinyu dan pencetak. Hasil perekayasaan alat pembuat kampas rem serat pulp ini dapat difungsikan sebagai alat produksi kala kecil atau untuk alat peraga penelitian kampas rem. Hasil pengujian produk kampas rem yang dihasilkan dari alat ini dapat memenuhi standar kampas rem kendaraan roda dua dan roda empat dengan nilai daya gesek 293-319, koefisien gesek $0,47-0,53$, suhu pengereman $70-110^{\circ} \mathrm{C}$ dengan tingkat kekerasan 7,0-8,0.

\section{$4.1 S A R A N$}

Mesin pembuat kampas rem serat pulp (non asbestos) ini, dapat dilakukan modifikasi atau perubahan untuk mencapai kapasitas produksi optimum sesuai target produksinya.

\section{UCAPAN TERIMA KASIH}

Disampaikan kepada :

1) Kepala Balai Besar Pulp dan Kertas (BBPK) Bandung

2) Bapak Arief Triwaskito direktur dan staf PT. Remindo Pratama, Kawasan Industri Krawang

3) Direktur PT.IBP, Majalengka

4) Rekan sejawat peneliti (IKA-PII) dan Perekayasa BBPK Kementerian Perindustrian RI.

5) Media elektronik dan cetak Tempo TV, Green Radio 89,2 FM, IPTEK Voice RRI Pro2 FM Jakarta, Bisnis Inovation Center (BIC 105), Harian Umum Media Indonesia atas promosi dan publikasinya.

Semoga hasil penelitian \& perekayasaan alat ini bermanfaat bagi masyarakat industri.

\section{DAFTAR PUSTAKA}

[1] Adelmann,1975 .Less Abrasive Composition Raillroad Btake Shoe Material,United State Patent No. 575306

[2] Kaminski, et.all, 1999. Method for Manufacturing Friction Materials Containing Blends of Organic Fibrous and Particulate Componens, Sterling Chemical International, Inc.Houston. TX

[3] Masmui, 2003. Pengembangan dan penerapan material komposit sebagai material gesek. Laporan kegiatan PPPTM-BPPT

[4] Mallawa, Cesarandie, 2010. Pengaruh Komposisi dan Diameter Serbuk Tempurung Kelapa Material Komposit Bahan Kampas Rem. Skripsi Teknik Mesin Universitas Hasanuddin, Makassar

[5] Mallawa, Cesarandie, 2010. Pengaruh Komposisi dan Diameter Serbuk Tempurung Kelapa Material Komposit Bahan Kampas Rem. Skripsi Teknik Mesin Universitas Hasanuddin, Makassar

[6] Waskito, Arif Tri ,2008 IBP Brake non Asbestos pad and linning. www.rni.co.id.

[7] Wawan Kartiwa, Arif Tri Waskito , 2008. Peningkatan standar kampas rem kendaraan berbahan asbestos dan nos asbestos untuk keamanan. Prosiding seminar BSN , ITB

[8] Wawan Kartiwa , Arif Tri Waskito , 2012. Pengembangan skala pilot kampas rem serat pulp untuk kendaraan roda dua. Prosiding Teknologi Pulp dan Kertas.

[9] Wawan Kartiwa Haroen, 2009 . Paten No.P.00200900599, Kampas rem kendaraan bermotor dari serat pulp, Dirjen Paten Kemenhumkam R.I.

[10] SNI.09-0143-1087 Kampas rem (brake linning) kendaraan bermotor roda empat (klasifikasi,dimensi dan koefisien gesek)

[11] SNI.09-1640-2002 Definisi dan istilah kendaraan beroda kurang dari empat. Badan Standardisasi Nasional

[12] SNI.09-2774-1992 Cara uji porositas kampas rem untuk kendaraan bermotor. Badan Standardisasi Nasional 